UDC 621.315.616.96.015.533: 621.3.018.756 537.523 .2 .096

論 文

48-A 53

\title{
広い温度範囲においてトリーの性状に 及ぼす印加電圧波形の影響
}

$\begin{array}{llll}\text { 明治大学 } & \text { 工 } & \text { 藤 } & \text { 勝 利 } \\ \text { 明治大学 } 山 & \text { 口 } & \text { 宗五郎 }\end{array}$

\section{1. まえがき}

近年，高分子材料の進歩沉伴い，ポリエチレンをは じぬとして有機材料方電気絶緑体として多方面に使用 されている。有機絶緑体はすぐれた電気的性質を持っ ているにあか力加らず，不平等電界のむとでは容易に 部分破壊汃引き起しされる場合があり，最終的には貫 通破壊侄る。

部分破壊である゙トリー・あるいは“トリーイング” は単に寒用上の問題ばかりではなく，広く絶縁体の破 壊機棈の面からあ與味ある問題を含えでいる。1951年 Mason 氏梳中放電の集中汇より放電孔を形成し， 去の先端からトリ一が伸びる可能性を指摘した。兵 の後, Kitchin 氏らか高電正用ポリエチレンケーブル に极いてトリ一の発生を確認したのが端緒となり，23 絶縁破填の前駆現敦としてのトリ一が注目在集めるよ うになった。トリ一性状は多くの人々により種々の観 点から調查，研究がなされ，その譏構についてはある 程度解明さ机てはいるが，種々不明な点屯多い。特に 温度に伴う絶縁体の物理的性瞔の变化住対応して，い

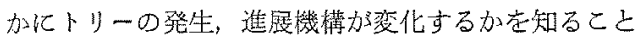
は重要な問題である。しかしながら，この分野におけ

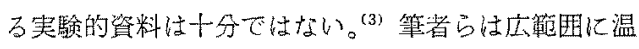
度を変化させ，交流電圧を印加した際のトリ一性状に ついてはいままでに発表してきた。(4)

今回, こ机引き綕き交流半波, インパルス電圧を

The Effect of Wave Form of Appliod Voltage on the Tree Characteristics Over a Wide Temperature Range. By K. KUDO, Member (Graduate School of Meiji University) \& S. YAMA. GUCH1, Member (Faculty of Engineering, Meiji University).

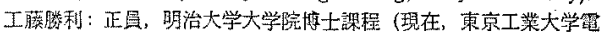
氛工学科助手)

山口宗五郎: 正䝿, 明治大学正学部教摱
印加した場合のトリー性状の温度倲存性を調查したと ころ, 非常に興味ある結果が得られた。すな加，温 度, 電生波形およで極性などにより,トリ一の発生, 進展がかなり異なった举動示すことが判明した。

本報告は主にトリ一性状の温度依存性についての串 験結果であり，それについての定性的な帑察を行なっ た。

\section{2. 試料および実験方法}

〈2.1〉供試料供試料としてはメルトインデッ クス(MI) 1.26 の低密度ポリエチレン(以下 PE と 略称), ポリメチルメタアクリレート(以下 PMMA と 略称）の 2 種類を用い，才法は $5 \sim 10 \times 12 \times 25 \mathrm{~mm} D$ ブロックである。第 1 図は試料の形状である。針電極 は No. 2 のメリケン針（約 $1 \mathrm{~mm} \phi$, 長さ約 $37 \mathrm{~mm}$ ) であり，針先端の角度が $30^{\circ}$, 曲率半径約 $5 \mu \mathrm{m}$ 飞标 るように回転研摩機で研摩してある。試料柱針電極そ う入固定ジグに取り付けられ，恒温そう内で加熱 ( $\mathrm{PE}$

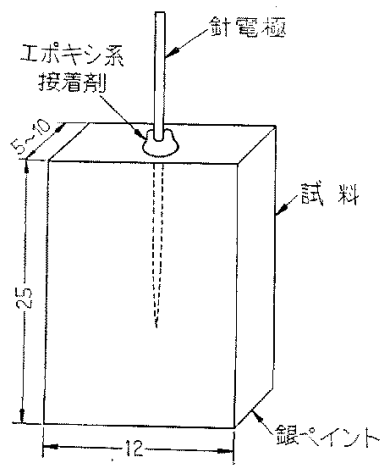

第 1 因試料口概现

Fig. 1. Schematic diagram of a specimen. 


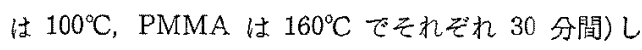
て針電極をう入し，そのままの状態で常温まで徐椧 してある。また，針の付け根はエポキシ樹脂系接着㓮 で固䚮てある。また，平板電極化接する試料面はすべ て銀ペント定染付した。一方，針電極加ら平板電極 までのギャップの長さは $10( \pm 0.5) \mathrm{mm}$ とした。

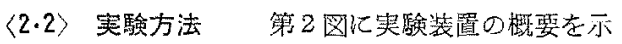
す。電極系は針対平板直接接地方式であり，針電極㑡 汇高王を印加した。使用した交流半波霞氏は交流 50 $\mathrm{Hz}$ を半波整流したものであり，インパルス電圧は標 準波 $(1 \times 40 \mu \mathrm{s})$ t用いた。常温での実験はモリブデ ンガラス容器にシリコーン油を淦たし，その中に試料 を浸せきして行なった。温度制御する場合は，モリブ

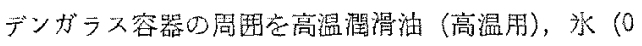

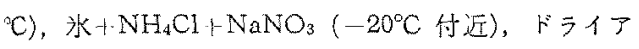

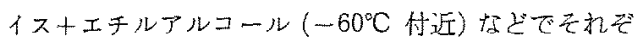
れ充てんしたが，しかしいずれの温度の場合で屯, 試 料自体はシリコーン油中に直接浸せきされている。た だし，液体公素の温度にする際は率熱被㠅を施したポ リエチレン容器に液体窒素を満たし，その中に試料を 直接浸せきした。いずれの場合も温度を規定値似保っ た後，坛料を全画浸せきし，10 分留経過してから電圧 を印加した。なお，トリーの観察は最大倍率 120 倍の 顕微鏡で行ない，針の中心軸方向に $20 \mu \mathrm{m}$ 程度まで伸 びたものをトリーの発生とした。

$\langle 2 \cdot 3\rangle$ 特性電圧の測定 $50 \%$ トリ一発生霥王,

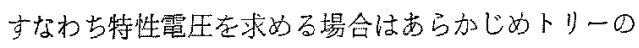
発生する笔生の見当をつけておき，その付近の雪圧在 選んで交流半波電圧の際は10 分間課電, 15 分間休止, $1 \mathrm{kV}$ 段觜景珐で決定する。またインパルス電压に関 しては，3発印加し，15 分間休上， $3 \mathrm{kV}$ の段階昇压 で行なった。交流半波およびインパルス電称と各温 度で 10 個の試料を用いた。

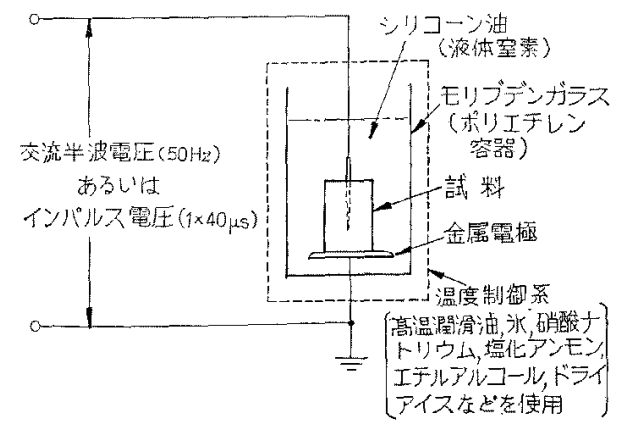

第 2 四 実駼淁置の概図

Fig. 2. Schematic diagram of experimental apparatus.

Vol. 93-A, No. 9

\section{3. 実験結果とその考察}

〈3.1〉特性電圧の温度㳖存性第3図および第 4 图任それぞれ PE, PMMA についての特性電压の变 化を示した委のである。比烄のために，前回(4)に報告 した交流霞㾏回加の際の特性雷生在波高值で示した。

一般的䫈向としては低温になるにつれて、トリ一発生 電死のばらつきが大きくなる。特化液体空溸温度にお ける PE 試泝の負極性のトリ一発生電圧は極度に高 く，しか子そのトリーは非常に進展しにくい。したが

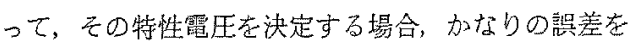
生ずる可能性がある。

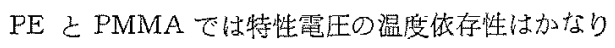
相专加認められ，PE は著しく温度に依存して抢り，

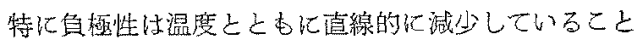

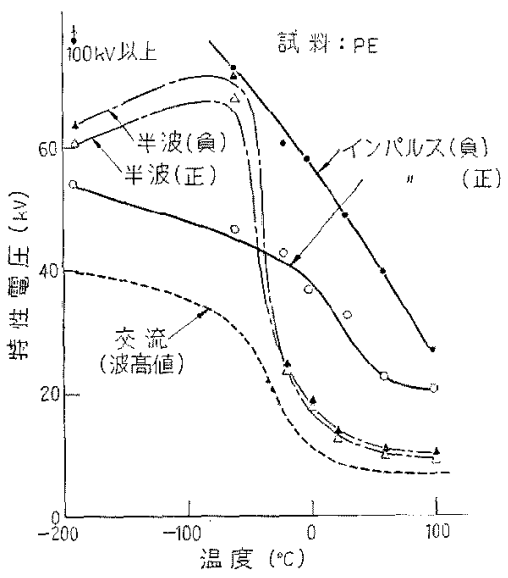

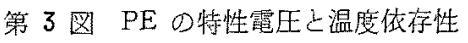

Fig. 3. Temperature dependence of characteristic voltage in $\mathrm{PE}$.

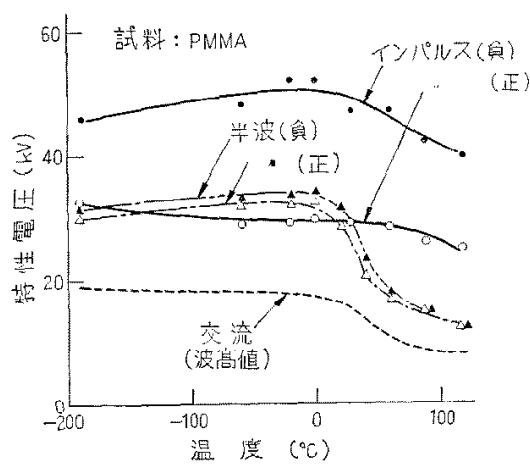

第 4 図 PMMA D特性電王の温度依存性

Fig. 4. Temperature dependence of characteristic voltage in PMMA. 
が注目される。これらの結果から特性電国の一般的な 傾向范列举してみると，

(i) インパルス㥜では極性差がはっきりしている 加，交流半波值で估比較的少ない。

(ii) 交流半波值は交流值上同じ傾问であり, $\mathrm{PE}$ の場合は $-60^{\circ} \sim 0^{\circ} \mathrm{C}$ て, PMMA の場合は $20^{\circ} \sim 60^{\circ} \mathrm{C}$

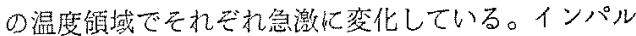
スではかかる温度镇域で異なる特性を示している。

(iii) 高温領域では正負インパルス値が上もに交流 半波健上り毛高い值を示しているが，低温領域に招い ては正のインパルス値と交流半波值の関缧が逆転して いる。この逆枟する温度預域は $\mathrm{PE}$ の場合は $-40^{\circ} \mathrm{C}$ 付近にあり，PMMA では常温付近にある。

PEのインパルス值は高温になると極性差が小さく なる傾向にある。

交流半波值では低温領域においてわずかに極性差が みら机，高温領域ではほとんど差異奆示さない。また Dittmer 氏は常温で一発の交流半波電压の場合，負極 性のほうがかなり高い電圧でトリーが発生することを

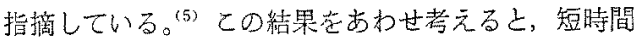
課電では極性差老生ずるが，課電時間が長くなるにつ れて極性差はなくるる委の上思われる。この原因比つ いて詳紬はわからないが，筷者らは次のように考えて

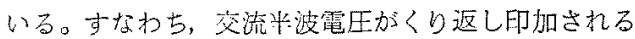
うちに，正抢上び負電極の針端周召に空閻電荷が形成

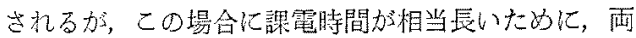
者の針端の電界がほほ等しくなるもの上推察される。 低温頜域ては空間篦荷形成の迤速に上りいくふん極性 差が㒛めら扎るようである。

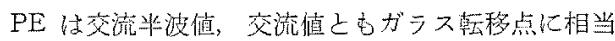
古ると思放れる $-60^{\circ} \mathrm{C}$ 付近から減少しはじかるが, PMMA ではガラス軽移混掏よりむかなり低い $40^{\circ} \mathrm{C}$ 付近加低下しはじめる。PMMAの $40^{\circ} \mathrm{C}$ 付近枕

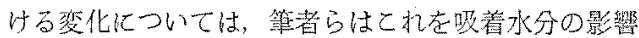
であるとの推定をくだした。(4)フィルム状試料の絶縁

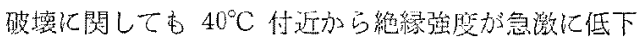
してゆくこしが認められている。(6) Artbauer 氏日こ

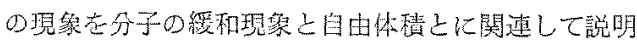
している。 ${ }^{72}$ との場合，インパルス㥀加交流值，交流

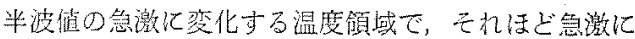
は変北していない事舁は時間に関係することが大なる しとを想わせる。

課電時間は空間電荷形成に関連する。しかしながら インパルス值に著しい極性のあるととから空間電何だ けでは説明できないすのがあり，新しい瀻楧を考える 必要があると思玑る。むた高温領域に执いては，課
電時間が長い波形ほど特性䉓死が低下している事実か ら，針端付近に未ける熱好果加大になる可能性も考无 られる。

〈3.2〉インパルス電圧によるトリーの僬展 第 5 图，第 6 図はそれぞれインパルス電代による $\mathrm{PE}$ ， PMMA のトリーの伸びを示す。この量合の印加方法 は正具相極性とす $75 \mathrm{kV}$ を1発印加した。用いた試 料山各温度とも5 個である。

トリーの伸びについむ発生の埼合と同じように極 性効果がみられ，一般に正極性の涪うが進展しやすい 傾向を示している。正極性においてはガラス䡆移温度 以上になると顕著なトリ一進展がみられるが，負極性 の場合はそれほど変化がみられない上うである。 $\mathrm{PE}$ の正極性に和いては $60^{\circ} \mathrm{C}$ 付近から高温頜域に扎いて

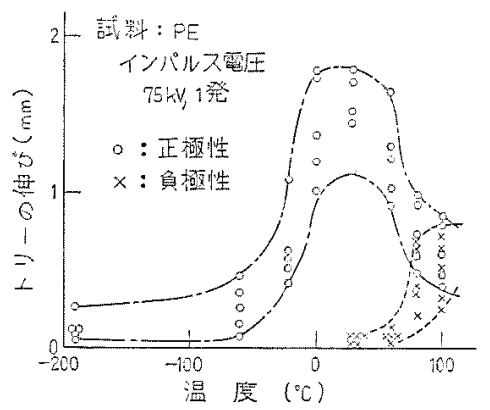

第 5 図 インパルス電压による PE のトリ 一の湖ひと温度の関係

Fig. 5. Relation between the growth of tree and temperature by a single impulse voltage (PE).

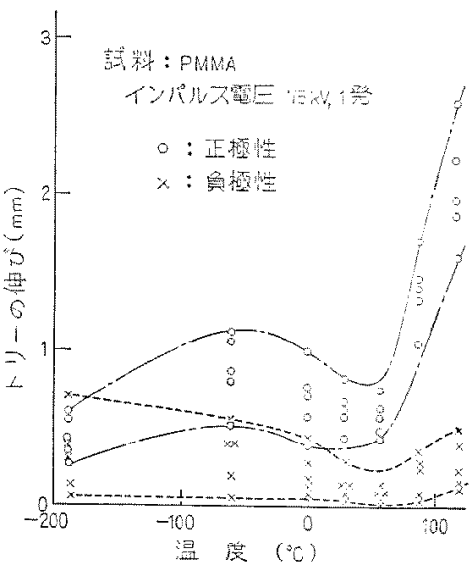

第 6 図 インパルス電压による PMMA D トリーの伸びと㯰度の関係

Fig. 6. Relation between the growth of tree and temperature by a single impulse voltage (PMMA). 


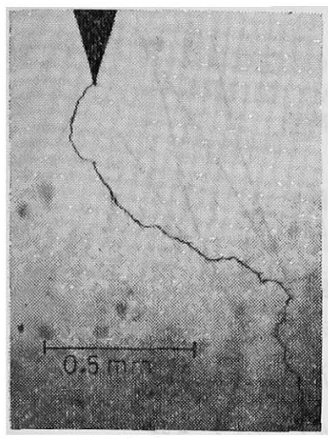

(a)

(a) $75 \mathrm{kV}$, 正極性, $19^{\circ} \mathrm{C}$

(b) $75 \mathrm{kV}$, 正極性, $80^{\circ} \mathrm{C}$

(c) $75 \mathrm{kV}$, 負極性, $80^{\circ} \mathrm{C}$

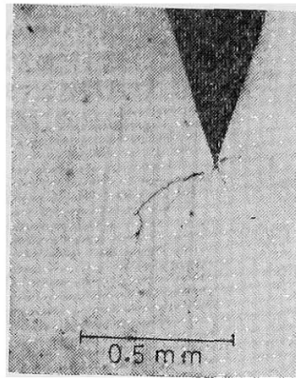

(b)

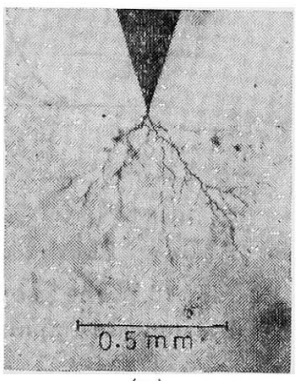

(c)

第 7 図 インパルス電压による $\mathrm{PE}$ 中の

$$
\text { トリーの伸び }
$$

Fig. 7. The shape of tree in $\mathrm{PE}$ by a single impulse voltage.
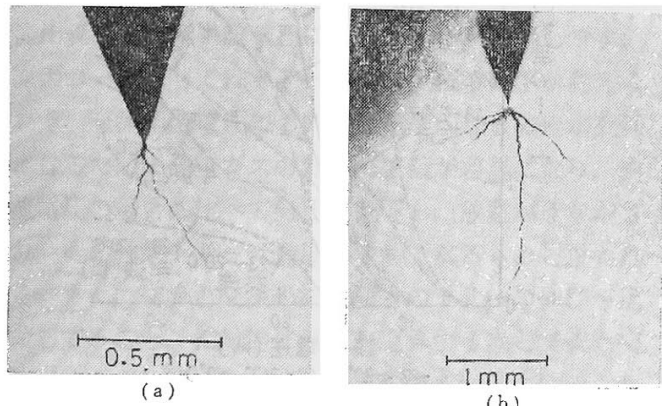

(b)

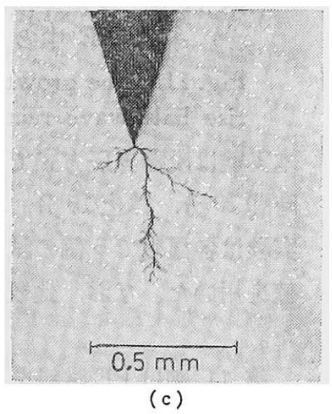

第 8 困 インパルス電圧による PMMA 中のトリーの伸び

Fig. 8. The shape of tree in PMMA by a single impulse voltage.
伸びが著しく減少しはじめるのに反し，負極性ではか なりの進展がみられ， $100^{\circ} \mathrm{C}$ 付近になると両極性によ る差異はほとんど認められなくなる。高温領域におい て正極性のトリーが進展しにくくなるのに反し, 負極 性が進展しやすくなっている原因について詳細はわか らないが，たとえば結晶性の変化に伴う構造上の問題 が考えら机よう。PE の結晶化度は $60^{\circ} \mathrm{C}$ 付近加ら減 少しはじめるとの結果が得られており, ${ }^{(8)}$ トリ一の伷 びぐあいと結晶化度がきわめて類似した温度特性走 している事実から相関性がうかがわれる。しかし，こ の伸びの異常性についてはさらに検討を要するむのと 思わ机る。なお，第 7 四，符8図化インパルス一発に よるトリーの伸びの様子の一部を示す。なお,トリー の伸びは針中心軸方向の伸びとして测定してあるが， $\mathrm{PE}$ の場合第 7 図にみられるように $80^{\circ} \mathrm{C}$ の正極性で は中心軸方向の伸びに比べて横方向の伸びが相対的に 大きくなる傾向がある。

これらの結果から明らかなように，インパルス電圧 を印加した場合のトリ一進展はかなり特異な挙動を示 しており，ての進展機棈をさらに詳細们調べるために 段階昇圧方式で実験を行なった。段階昇圧はただ一発 の場合よりむ材料物性との相関性が大きくあらわ机る と之あ考えられるので，ての上うな観点から段階昇压 方式を用いた。

第 9 図は $\mathrm{PE}$ 試料を用い，それぞれ $-20^{\circ} \mathrm{C}$ 付近， 常温， $60^{\circ} \mathrm{C}$ および $80^{\circ} \mathrm{C}$ におけるトリ一の伸びについ て示してある。この場合, 初期電圧 $30 \mathrm{kV}, 10 \mathrm{kV} / 1$ 発の段階昇圧で行なった。用いた試料注各温度とも 5 個である。段階昇圧におけるトリ一の伸びは前述のイ ンパルス 1 発の場合上同じような伸びの特性示して 拈り，やはり $80^{\circ} \mathrm{C}$ に扰けるトリーは $60^{\circ} \mathrm{C}$ に比へてて 進展しにくい傾向がみら机る。一般に正極性の場合は ある電圧以上になると急激にトリーが進展することが わかる。一方，負極性においては正極性に比べてきわ めて進展しにくい傾向ではあるが，高温になるに従い トリーは進展しやすくなり， $80^{\circ} \mathrm{C}$ の場合注正両極 性によるトリーの伸びの差異は少なくなる。このよう 海高温領域汇甫いて，正極性は進展しにくいのに対し て，逆に負極性では進展しやすい傾向を示している事 実はトリ一進展機構を考察するうえで重要な結果之思 わ机る。

第 10 図はPMMA 試料を用い, 常温乾よび $80^{\circ} \mathrm{C}$ に打けるトリーの進展を示す。常温と $80^{\circ} \mathrm{C}$ の伸びを 比較してみると，温度に上る影響はそれほどみられ ず，80ㄷ までは伸びの傾向としてはあまり変化しな いようである。ただし，前述のインパルス1発による 


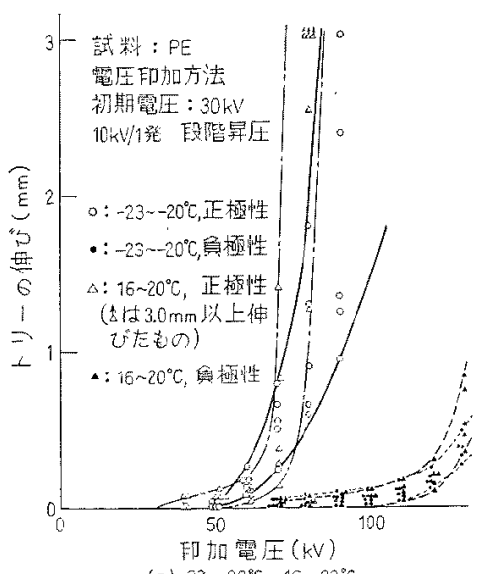

(a) $-23 \sim-20^{\circ} \mathrm{C}, \quad 16 \sim 20^{\circ} \mathrm{C}$

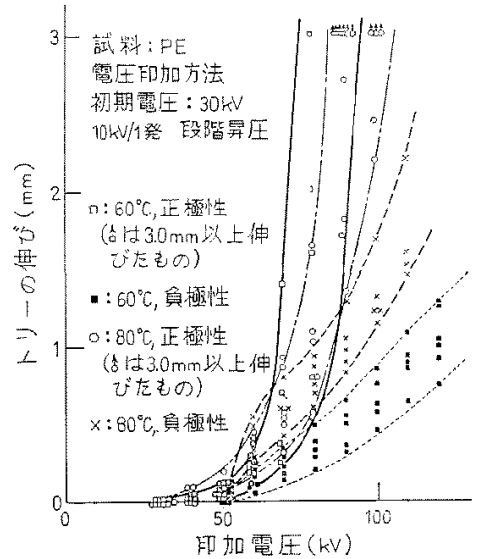

(b) $60^{\circ} \mathrm{C}, 80^{\circ} \mathrm{C}$

第 9 图 インパルス電压(段階㫧生)に上る PEのトリーの㑲び

Fig. 9. The growth of tree in PE by step. rise impulse voltage.

結果加らする己，段階昇圧方式の場合も $90^{\circ} \mathrm{C}$ 付近か ら急激にトリーが進展することが推察される。

以上の結果加らすると，或階景圧の場合屯インパル ス 1 発に上る啺合と同様な傾向を示しており，材料物 性上の相関性屯大差が括くあらわれる。このとと加ら 段階孀圧の埸合のヒステリシス効果などがトリ一進展

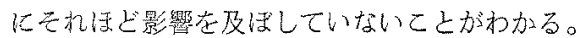

〈3・3〉 交流半波電圧によるトリーの進展＼cjkstart交流 管王は交互に極性を变えながら連秎的に印加されてい る状態であり，したがってそのトリ一進展機满はかな り複䧴になっているととが考えられる。そ0点，交流 半波䉓在は単極性であり，加つ間欠的印加の状態であ るた好に，交流電王印加の際のトリ一進展機構とかな り買なる特性を与えるこが考えられる。

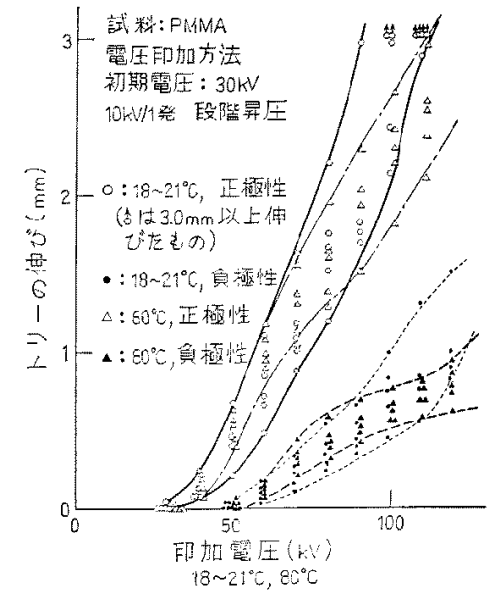

第 10 图 インパルス電生(段階界圧)による PMMA のトリーの伸び

Fig. 10. The growth of tree in PMMA by step-rise impulse voltage.

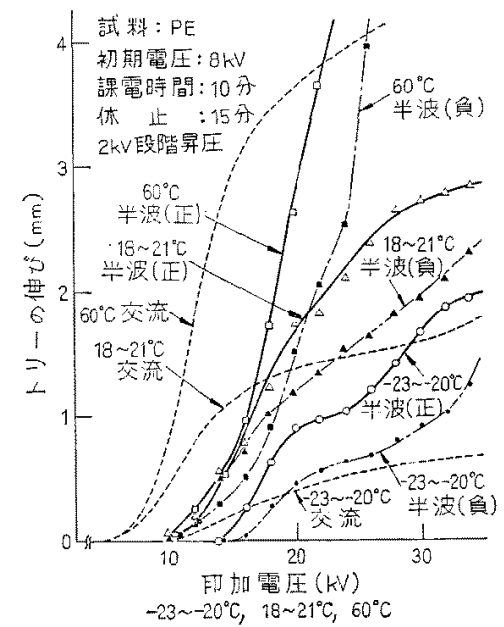

第 11 図 交流半波電圧（段陆昇王）による $\mathrm{PE}$ 中のトリーの伸び

Fig. 11. The growth of tree in PE by steprise half wave rectified voltage of $\mathrm{AC}$. 本実験は段階昇圧方式で苛り，初期電压 $8 \mathrm{kV}$ ，課電 時閩 10 分，休止 15 分， $2 \mathrm{kV}$ 段階昇圧で行なった。 実駼は各温度で 5 個の試料について行ない，その平均 值を用いた。な招，比較のために交流電代値も示し た。

第 11 図はPE 試料を用い，そ机ぞれ $-20^{\circ} \mathrm{C}$ 付近， 常温，60年におけるトリ一の伸びを示してある。な

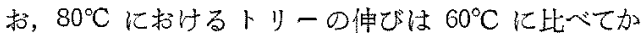
なり進展しやすく，ほとんどの試料が途中て側面破壊 をしたために本文中にはえの実験結果を記載していな 


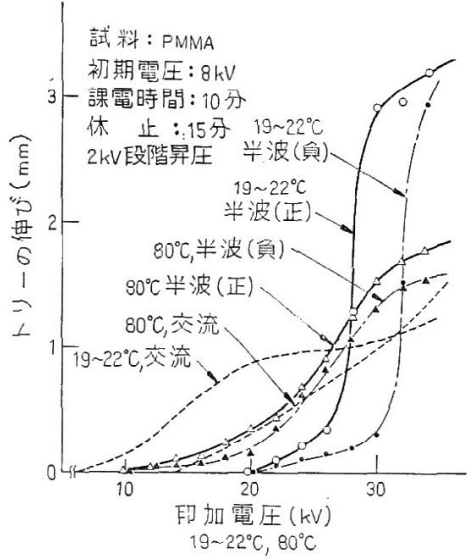

第 12 図 交流半波電圧(段階昇圧) による PMMA 中のトリーの伸び

Fig. 12. The growth of tree in PMMA by step-rise half wave rectified voltage of $\mathrm{AC}$.

い。また，第 12 図は PMMA 試料の伸びであり，常 温, $80^{\circ} \mathrm{C}$ について示してある。交流半波電圧の場合 は交流電圧と比べてトリー発生電圧は高々, 低電圧で は進展が緩慢であるが, 電圧が高くなるにつれて進展 しやすい傾向である。また，正の交流半波電圧は負の 場合よりも進展しやすいとと屯特徴である。交流電压 に比較して交流半波電圧によるトリーが進展しやすい 原因の一つとしてはトリー内部の気圧の低下が考えら れる。交流半波電开においては電圧印加と休止が交互 になるために発生ガスの屚れ, 拡散が容易になり, 交 流電圧の場合に比べて気压が低下し，放電がうながさ れ，その結果トリーは進展しやすくなるものと思われ る。また，交流と交流半波電圧とのトリーの伸びを比 較してみると, 相対的に温度が上昇するほど交流と交 流半波との伸びの差がなくなる傾向を示している。高 い温度では分解ガスの且力およびトリー先端部の熱効 果などの複雑な機構の組合せにより, 交流と交流半波 との伸びにあまり差があらわれないむのと思われる。

ところで; トリー進展はその形状と密接に関係して おり，一般にはトリー状トリーで進展してゆく場合は かなり急速であるが，ブッシュ状あるいはクラック状 トリーに近い形状の場合は緩慢に進展してゆくことが わかる。PMMA の交流半波電圧によるトリーの様子 の一部を第 13 四，第 14 図にそれぞれ示す。PMMA

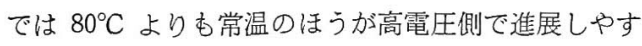
くなっており，そのトリ一形状にむかなりの相違が認 められ，常温の場合はトリー状トリーであるが， $80^{\circ} \mathrm{C}$ になるとブッシュ状に近いトリー形状となっている。

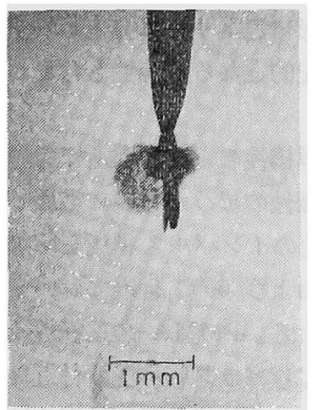

(a) 交流 $30 \mathrm{kV}$

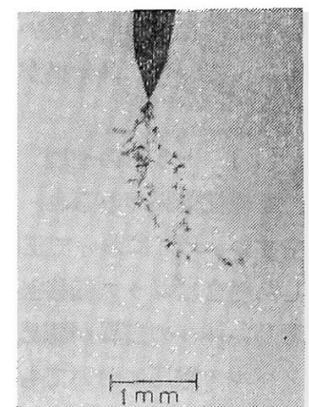

(b) 交流半波(正) $30 \mathrm{kV}$
第 13 図 交流上交流半波電化に上る PMMA 中のトリーの形状 $\left(21^{\circ} \mathrm{C}\right)$

Fig. 13. The shape of trees in PMMA by the difference of $\mathrm{AC}$ and its rectified voltages. $\left(21^{\circ} \mathrm{C}\right)$

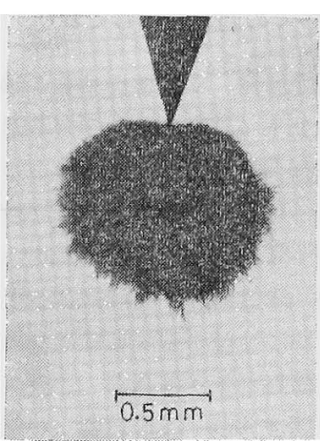

(a) 交流 $30 \mathrm{kV}$

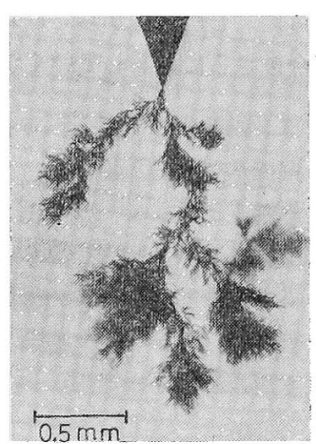

(b) 交流半波(正) $30 \mathrm{kV}$
第 14 図 交流と交流半波電圧による PMMA 中のトリーの形状 $\left(80^{\circ} \mathrm{C}\right)$

Fig. 14. The shape of trees in PMMA by the difference of $\mathrm{AC}$ and its rectified voltages $\left(80^{\circ} \mathrm{C}\right)$.

\section{4.むすび}

箻者らは，PEと PMMA 試料を用いてトリ一の発 生, 進展機構を考察したが, 液体窒素温度から $120^{\circ} \mathrm{C}$ 付近までの温度範囲では材料の種類, 温度, 電圧波形 などにより著しく相違していることがわかった。その 結果を要約すると次のようである。

（1）トリーの発生単極性（インパルス, 交流 半波電厌) では極性効果があられ，インパルスの場合 は著しい極性差が認められ，特に低温領域では極性効 果が重要と思われる。交流々交流半波電圧のような摖 電時間の相当長い場合には，材料自身の挙動，たとえ ば分子運動に対応してトリー発生電圧は变化するよう であるが，インパルス電圧のように短時間課電ではこ の関係は緊密でないようである。さらに高温領域にお 
いては，熘電時閒が長い波北はよ゙トリーは発生しやす

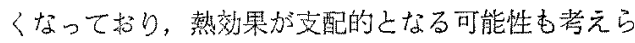
机る。

（2）トリ一の谁展紧極性のトリ一進展につい

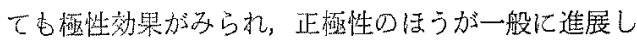
やすい。PEにおいて正極性のインパルス電压を印加 した場含はダラス転移温度㥂よび $60^{\circ} \mathrm{C}$ 付近に招いて

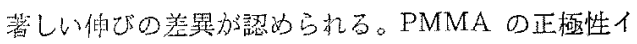

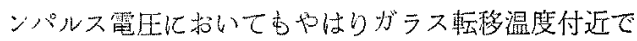
徣しい俳ず加みら㧈る。また，交流半波電王は交流に

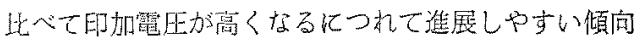

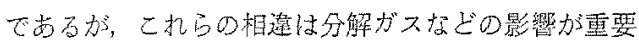
な役㫼を果たしているあのと考えられる。

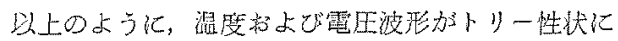

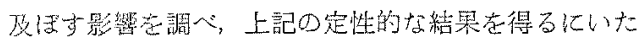

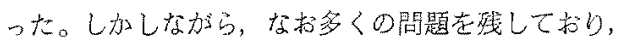
今後さらに檢討していく予定である。
䅂わりに，本研究に対して終始，で指導，でへんた つを賜わった青山学院大学教授斎藤幸男博士，本学教 授田中座蔵諱上に感謝の意老します。また，奏験に 㙝力していただいた本学大学院生日向野柴氏, 武料を 提供していただいた昭和電楾笪纜株式会社に求礼申し 上げます。

(昭和 47 年 7 月 29 日受付, 同 48 年 5 月 19 日再受付)

\section{文献}

(1) J.H. Mason: Proc. Instr Elect. Engrs 98, 1, 44 (1951)

(2) D.W. Kitchin \& O.S. Pratt: Trans. Amer. Inst. Elect. Engr\$ 77, III, 180 (1958)

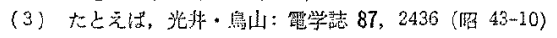

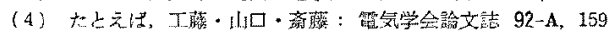
(昭 $47-4$ )

(5) B. Ditmer: Arch. Electrotech. III, Heft 6, 387 (1964)

(6) W. G. Oakes: J. Inst. Elect. Engrs 96, 1, 37 (1949)

(7) J. Artbaver: たzえば, J. Polymer Sci, 16, 477 (1967)

(8) W. G. Cakes: J. Inst. Elect. Engrs 95, I, 36 (1948) 